\title{
Impact of Physical Education Teachers' Training Programme on Development of Achievement Motivation
}

\author{
Somnath Nandy ${ }^{1}$, Madhab Chandra Ghosh ${ }^{2}$, Samirranjan Adhikari ${ }^{3}$ \\ ${ }^{1}$ Research Scholar, Department of Physical Education, University of Kalyani, Kalyani, Nadia, W. B., India. \\ ${ }^{2}$ Associate Professor, Department of Physical Education, University of Kalyani, Kalyani, Nadia, W.B., India \\ ${ }^{3}$ Assistant Professor in Psychology, Shimurali Sachinandan College of Education, Shimurali, Nadia, W.B., India
}

\begin{abstract}
Achievement motivation is the acquired tendency and one of the most important social needs. It is a disposition to strive for success in competition with others with some standard of excellence, set by the individual. In physical education teacher training curriculum there is ample scope of rigorous physical activity as well as educational and mental exercise; so the main goal of the present study was to ascertain the impact of this training in development of Achievement Motivation. This one was a longitudinal study carried out through quasi-experimental research design. A sample of 200 B.P.Ed students was chosen from different teacher education institutions of West Bengal by stratified random sampling technique. Deo-Mohan Achievement Motivation Scale (n-Ach) was administered on the sample in three different phases - at the beginning, in the middle and at the end of the session. From the Paired Samples " $t$ " - test it was observed that there was statistically significant increase in the mean of the Sports Achievement Motivation scores from the $1^{\text {st }}$ phase (M $=16.86)$ to the $2^{\text {nd }}$ phase of testing $(M=17.90)$ and again to the $3^{\text {rd }}$ phase of testing $(M=18.82)$. Again, the means of the Total Achievement Motivation scores was statistically significant increase from the $1^{\text {st }}$ phase $(M=$ $158.07)$ to the $2^{\text {nd }}$ phase of testing $(M=171.06)$, and again to the $3^{\text {rd }}$ phase of testing $(M=184.07)$.
\end{abstract}

Key Words: Motivation, Achievement Motivation, Physical Education Teachers' Training Programme, Quasi-Experimental Research Design,

\section{Introduction}

Achievement motivation is the acquired tendency and one of the most important social needs (Newcomb, 1964) [1]. It has been defined by McClelland et al. (1953) [2] as a disposition to strive for success in competition with others with some standard of excellence, set by the individual. Motive to achieve requires an act of some norm of excellence, long-term involvement and unique accomplishment. In fact, this is one of the most important manifest and social needs and personality variable enlisted by Murray (1964) [3]. Classic achievement goal theorist, Murray (1938) [4], provided a formal definition for dispositional motivation and two achievement-relevant needs (need for achievement, fear of failure). The research foundation of Lewin and Murray paved the way for Atkinson (1957) [5] and McClelland (1953) [2], who developed a need for achievement theory. Within Atkinson's achievement theory, he offered two achievement strivings (one towards success, the other away from failure), which were the beginnings of the approach-avoidance distinction. According to Atkinson, an individual's achievement behaviour is influenced by expectancy of achieving a desired outcome and the value an individual places upon the outcome. Until the 1970s and 1980s, Atkinson's need for achievement theory dominated the achievement motivation literature. In the late 20th century, Dweck (1986) [6], Nicholls (1984) [7] and Ames (1984) [8] began to use an achievement goal approach to studying motivation. This shift from a classic to a contemporary approach led theorists to examine more global dispositions like attributions. Using this approach, researchers and practitioners are interested in understanding goal-directed behaviors. The foundation of the contemporary approach is the notion that individuals adopt goal orientations based on their achievement settings. These goal orientations are hypothesized to produce a unique set of processes and outcomes. Now in Physical Education is an important educational process that has as its aim the improvement of human performance and enhancement of human development through the medium of physical activities to realize this out come. It is a vital element in a comprehensive well balanced curriculum and can be a major contributing factor in the development of an individual in all aspects of life: physical, emotional, mental and social. Physical education with its wide varied rich store of activities and its contributions towards attainment of the desires human objectives, has found the rightful place in the world of education. Teachers training courses in physical education i.e. B.P.Ed. is an intensive training course in physical education. Both pedagogical and physical activities are included in the curriculum of B.P.Ed. course. The impact of this course on the development of some psychological and physical characteristics has been studied earlier by several researchers (Adhikari, 2008; 2010 and 2010a) [9], [10], [11]. 


\section{Objective of the study}

Physical education takes a crucial role in general education. However, a few numbers of studies are there to probe into the impact of physical education on various psychosocial and moral developments. Again, there is much theoretical speculation and empirical research about the effect of physical education on somatic and mental developmental; but the impact physical education on spiritual development has yet to be probed into. The present study is designed to explore the impact of B. P. Ed. Course on Development of Achievement Motivation.

\section{Method}

The present study was carried out through the method of experimental research with one-group Pre-test - Post-test design. The details regarding sample, tools, procedure of data collection and statistical technique are reported herewith.

3.1 Sample : Colleges and University Departments, imparting B.P.Ed. Course in West Bengal were our source of sample. Total sample size of the present study was 200 (Male=160 and Female=40). Stratified Random Sampling Technique was adopted in drawing sample. Only Bengali speaking subjects were taken. The Mean and S.D. of the ages of the B.P.Ed. Students were 24.07 and 2.095.

3.2 Research Tool : Deo-Mohan Achievement Motivation Scale (n-Ach): Deo and Mohan (2002) [12] have developed a scale to measure achievement motivation. This scale has 50 items. Items of this scale have also been constructed in reverse- and non-reverse-keyed format, and instructions are given asking participants to rate their agreement with a statement on 5-point "Likert type scale". This scale measures 15 factors and these are -

a) Academic Motivation,

b) Need for Achievement,

c) Academic Challenge,

d) Achievement Anxiety,

e) Importance of Grades/Marks,

f) Meaningfulness of task,

g) Relevance of School/College to Future Goal,

h) Attitude towards Education,

i) Work method,

j) Attitude towards Teachers,

k) Interpersonal Relations,

1) Individual Concern,

m) General Interests,

n) Dramatics,

o) Sports Etc.

For simplicity, sports achievement motivation and total achievement motivation were considered in this study.

3.3 Procedure : "Deo-Mohan Achievement Motivation Scale (n-Ach)" administered on the subjects in three different phases during the academic session 2006-07 and the responses were scored as per scoring procedure, prescribed in the manual.

The tool was administered in the following three phases -

a) In the first phase, the test was administered at the beginning of the B.P.Ed. course (in the $1^{\text {st }}$ week of July, 2006);

b) In the second phase the same test was administered in the middle of the course ( $3^{\text {rd }}$ week of November, 2006); and

c) In the final phase, the same test was administered at the completion of the course ( $1^{\text {st }}$ week of April, 2007, before study leave).

3.4 Statistical Analysis : Paired Samples " $t$ " - test was done with the help of SPSS 13.0 software.

\section{Results}

Result of the present investigation is furnished in the following tables. 
Impact of Physical Education Teachers' Training Programme on Development of Achievement

Table - 1: Paired Samples Statistics of Scores in Achievement Motivation

(Sports \& Total) of Different Phases of Study

\begin{tabular}{|c|l|c|c|c|}
\hline \multicolumn{2}{|c|}{ Variable } & Mean & N & S.D. \\
\hline Pair $_{1}$ & Sports $_{1}$ & 16.86 & 200 & 3.04 \\
\cline { 2 - 5 } & Sports $_{2}$ & 17.90 & 200 & 2.17 \\
\hline Pair $_{2}$ & Sports $_{2}$ & 17.90 & 200 & 2.17 \\
\cline { 2 - 5 } & Sports $_{3}$ & 18.82 & 200 & 1.79 \\
\hline Pair $_{3}$ & Sports $_{1}$ & 16.86 & 200 & 3.04 \\
\cline { 2 - 5 } & Sports $_{3}$ & 18.82 & 200 & 1.79 \\
\hline Pair $_{4}$ & Total $_{1}$ & 158.07 & 200 & 16.56 \\
\cline { 2 - 5 } & Total $_{2}$ & 171.06 & 200 & 11.40 \\
\hline Pair $_{5}$ & Total $_{2}$ & 171.06 & 200 & 11.40 \\
\cline { 2 - 5 } & Total $_{3}$ & 184.07 & 200 & 8.42 \\
\hline Pair $_{6}$ & Total $_{1}$ & 158.07 & 200 & 16.56 \\
\cline { 2 - 5 } & Total $_{3}$ & 184.07 & 200 & 8.42 \\
\hline
\end{tabular}

Table- 1 transpires that the mean of the Sports Achievement Motivation scores in the $1^{\text {st }}$ phase of testing was 16.86 , in the $2^{\text {nd }}$ phase of testing was 17.90 and in the $3^{\text {rd }}$ phase of testing was 18.82 . The mean of the Total Achievement Motivation scores in the $1^{\text {st }}$ phase of testing was 158.07 , in the $2^{\text {nd }}$ phase of testing was171.06 and in the $3^{\text {rd }}$ phase of testing was 184.07.

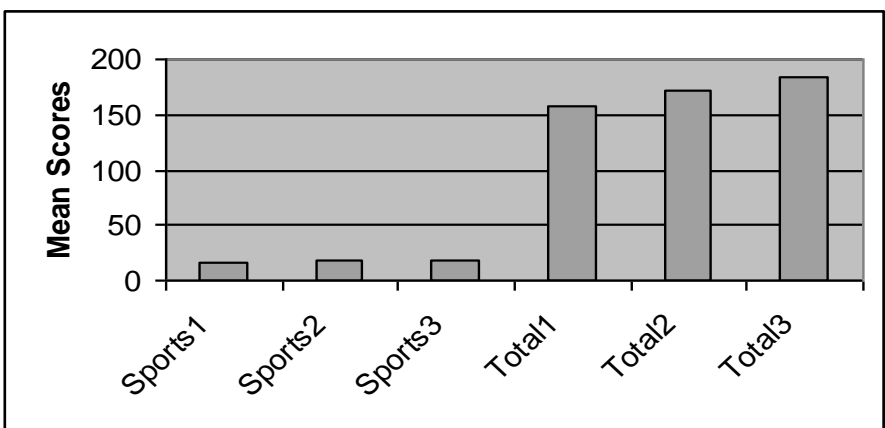

Figure - 1: Mean of Achievement motivation (Sports \& Total) Facets Scores in Different Phases of Study.

Table-2: Paired Samples Correlations among Scores in Achievement Motivation (Sports \& Total) of Different Phases of Study

\begin{tabular}{|l|c|c|c|c|}
\hline \multicolumn{2}{|c|}{ Variable } & N & Correlation & Sig. \\
\hline Pair $_{1}$ & Sports $_{1} \&$ Sports $_{2}$ & 200 & 0.939 & 0.000 \\
\hline Pair $_{2}$ & Sports $_{2} \&$ Sports $_{3}$ & 200 & 0.805 & 0.000 \\
\hline Pair $_{3}$ & Sports $_{1} \&$ Sports $_{3}$ & 200 & 0.785 & 0.000 \\
\hline Pair $_{4}$ & Total $_{1} \&$ Total $_{2}$ & 200 & 0.921 & 0.000 \\
\hline Pair $_{5}$ & Total $_{2} \&$ Total $_{3}$ & 200 & 0.897 & 0.000 \\
\hline Pair $_{6}$ & Total $_{1} \&$ Total $_{3}$ & 200 & 0.811 & 0.000 \\
\hline
\end{tabular}

From Table-2 it is observed that the coefficients of correlations of Sports Achievement Motivation scores between the in the $1^{\text {st }} \& 2^{\text {nd }}$ phase of testing was 0.939 , between the $2^{\text {nd }} \& 3^{\text {rd }}$ phase of testing was 0.805 and between the $1^{\text {st }} \& 3^{\text {rd }}$ phase of testing was 0.785 . It is also observed that the coefficients of correlations of Total Achievement Motivation scores between the $1^{\text {st }} \& 2^{\text {nd }}$ phase of testing was 0.921 , between the $2^{\text {nd }} \& 3^{\text {rd }}$ phase of testing was 0.897 and between the $1^{\text {st }} \& 3^{\text {rd }}$ phase of testing was 0.811 . All correlations were highly (statistically) significant.

Table-3: Paired Samples Test of Scores in Achievement Motivation (Sports \& Total) of Different Phases of Study

\begin{tabular}{|l|c|c|c|c|c|c|}
\hline \multirow{2}{*}{ Variable } & \multicolumn{2}{|c|}{ Paired Differences } & \multirow{2}{*}{ d } & \multirow{2}{*}{ Sig. (2-tailed) } \\
\cline { 3 - 4 } \multicolumn{2}{|c|}{} & Mean & S.D. & & & \\
\hline Pair $_{1}$ & Sports $_{1}-$ Sports $_{2}$ & -1.04 & 1.25 & -11.713 & 199 & 0.000 \\
\hline Pair $_{2}$ & Sports $_{2}-$ Sports $_{3}$ & -0.92 & 1.29 & -10.055 & 199 & 0.000 \\
\hline Pair $_{3}$ & Sports $_{1}-$ Sports $_{3}$ & -1.95 & 1.97 & -13.988 & 199 & 0.000 \\
\hline Pair $_{4}$ & Total $_{1}-$ Total $_{2}$ & -12.99 & 7.51 & -24.474 & 199 & 0.000 \\
\hline Pair $_{5}$ & Total $_{2}-$ Total $_{3}$ & -13.00 & 5.34 & -34.410 & 199 & 0.000 \\
\hline Pair $_{6}$ & Total $_{1}-$ Total $_{3}$ & -26.00 & 10.91 & -33.697 & 199 & 0.000 \\
\hline
\end{tabular}


Impact of Physical Education Teachers' Training Programme on Development of Achievement

From Table-3 it is observed that the mean of the both Sports and Total Achievement Motivation scores

of the B.P.Ed. Students increased significantly as the course was advanced towards the completion.

\section{Discussions and Conclusion}

From the result it was observed that the mean of the both Sports and Total Achievement Motivation scores of the B.P.Ed. Students increased significantly as the course was advanced towards the completion. Performance in physical activity is assumed to be important in the socialization process of the child. It is generally assumed that in play, games, and sport, children are brought into contact with social order and the values inherent in society, and are provided a context within which desirable social behaviours are developed (Brustad, 1993) [13]; (Evans and Roberts, 1987) [14]. This assumption has given rise to cultural expectations that have resulted in steadily increasing levels of involvement of children in all aspects of physical activity, especially adult organized competitive sport. Research has demonstrated that the domain of competitive sport is a particularly important context for psycho-social development in that peer status, peer acceptance, and selfworth are established and developed (Evans and Roberts, 19870 [14]; (Fox, 1988) [15]; $\quad$ ( Veroff, 1969) [16]. These social attributes are based upon many factors, but one way a child can gain acceptance is to demonstrate competence in an activity valued by other children. One area of competence highly valued by children is athletic ability (Chase and Drummer, 1992) [17]; (Roberts and Treasure, 1992, 1993) [18], [19]. Being a good athlete appears to be a strong social asset for a child, especially for boys. Thus, understanding the social dynamics of involvement and enhancing the achievement behaviour of children in competitive sport contexts has been a topic of considerable interest for coaches, teachers, and parents.

Recent research has applied and tested the conceptual relevance of achievement goal theory to the domain of sport. This line of research has focused on identifying the cognitive and behavioral concomitants of task and ego orientations (Duda, 1989) [20]; (Duda, Fox, Biddle, and Armstrong, 1992) [21]; (Lochbaum and Roberts, 1993) [22]; (Roberts and Treasure, 1995) [23]; (Treasure and Roberts, 1994a) [24], and has consistently demonstrated that the conceptually coherent relationship between achievement goals and beliefs that has emerged in the education setting, also exist in sport (Duda, 1993) [25]; (Roberts, 1993) [26]. Determining the antecedents of individual differences in achievement goal orientation has, however, received little attention in the sport literature (Brustad, 1993) [13]. One antecedent of dispositional achievement goal orientations to receive some attention recently has been parental beliefs.

\section{References}

[1] Newcomb, T.M., Motivation. In Gould . J. and Kolb, W. L. (Ed.),A Dictionary of the Social Sciences. New York: The Free Press, p. 447-448, 1964.

[2] McClelland, D.C., Atkinson, J.W., Clark, R.A. and Lowell, E.L., The achievement motive, New York: Appleton-Century-Crofts, 1953.

[3] Murray, E.J., Motivation and emotion. Englewood cliffs, NJ: Prentice-Hall, 1964.

[4] Murray, H., Exploration of Personality. New York: Oxford University Press, 1938.

[5] Atkinson, N., \& Permuth-Levine, R., Benefits, Barriers, and Cues to Action of Yoga Practice: A Focus Group Approach. Manuscript submitted for publication, 2007,

[6] Dweck, C. S., Motivational processes affecting learning. American Psychologist, 41, 1040-1048, 1986.

[7] Nicholls, J. G., Achievement motivation: Conceptions of ability, subjective experience, task choice, and performance. Psychological Review, 91, 328-346, 1984.

[8] Ames, C., Competitive, cooperative and individualistic goal structures: A cognitive motivational analysis. In C. Ames \& R. Ames (Eds.), Research on motivation in education (Vol. 3, pp. 177-207). New York: Academic Press, 1984

[9] Adhikari, S., Perfectionist Self-Presentation Style of Prospective General as well as Physical Education Teachers. Indian Psychological Review, Vol. 71, No. Special Issue, 2008.

[10] Adhikari, S., Impact of Physical Education Teachers Training Programme on Experience of Purpose of Life. Indian Psychological Review, Vol. 74 No. 2 Yr., 2010

[11] Adhikari, S., To Study the Experience of Purpose in Life of Prospective General as well as Physical Education Teachers. Asian Journal of psychology \& Education, Vol. Vol. 43 No. 3-4 Yr., 2010a

[12] Deo, P. and Mohan, A., Manual for Deo-Mohan achievement motivation scale. National Psychological Corporation, Agra, 2002

[13] Brustad, R.J., Who will go out and play? Parental and psychological influences on children's attraction to physical activity. Pediatric Science, 5, 210-223, 1993.

[14] Evans, J., \& Roberts, G. C., Physical competence and the development of children's peer relations. Quest, 39, $23-35,1987$.

[15] Fox, R. E., Prescription privileges: Their implications for the practice of psychology. Psychotherapy, 25, 501-507, 1988.

[16] Veroff, J., Social comparison and the development of achievement motivation. In C. Smith (Ed.), Achievement related motivation in children (pp. 46-101). New York: Russell Sage Foundation, 1969.

[17] Chase, M. A., \& Dummer, G. M., The role of sports as a social status determinant for children. Research Quarterly for Exercise and Sport, 63, 418-424, 1992.

[18] Roberts, G. C. and Treasure, D., Children in sport. Sport Science Review. 1 (2) 46-64, 1992.

[19] Roberts, G. C. and Treasure, D. C., The importance of the study of children in sport: An overview. In M. Lee (Ed.) Coaching Children in Sport: Principles and Practice. (pp 1-16) London: E and F N Spon, 1993.

[20] Duda, J. L., Relationship between task and ego orientation and the perceived purposes of sport among high school athletes. Journal of Sport and Exercise Psychology, 11, 318-335, 1989.

[21] Duda, J. L., Fox, K. R., Biddle, S. J. H., and Armstrong, N., Children's achievement goals and beliefs about success in sport. British Journal of Educational Psychology, 84, 1-10, 1992. 
[22] Lochbaum, M., and Roberts, G. C., Goal orientations and perceptions of the sport experience. Journal of Sport and Exercise Psychology, 15, 160-171, 1993.

[23] Roberts, G. C., and Treasure, D. C., Achievement goals, motivational climate, and achievement strategies and behaviors in sport. International Journal of Sport Psychology. 26 (1), 64-80, 1995.

[24] Treasure, D. C., and Roberts, G. C., Cognitive and affective concomitants of task and ego goal orientations during the middleschool years. Journal of Sport and Exercise Psychology, 16, 15-28, 1994a.

[25] Duda, J. L., Goals: A social cognitive approach to the study of achievement motivation in sport. In R. N. Singer, M. Murphey, and L. K. Tennant (Eds.), Handbook of research on sport psychology (pp. 421-436). Macmillan: New York, 1993.

[26] Roberts, G., Motivation in sport: Understanding and enhancing the motivation and achievement of children. In R. N. Singer, M. Murphey, \& L. K. Tennant (Eds.), Handbook of research on sport psychology (pp. 405-420). New York: MacMillan, 1993. 